\title{
The impact of the Law on Strengthening the Security of Financial Relations on the value relevance of accounting information in Tunisian Stock Exchange
}

\author{
Mohamed Rafik BEN AYED (Corresponding author) \\ Assistant Professor. Département : Comptabilité-Finance \\ Institut Supérieur de Gestion de Tunis, Université de Tunis. Tunisia \\ Phone : 0021623552398 Fax :0021671584599 Email: rafik.ben-ayed@laposte.net
}

\author{
Ezzeddine ABAOUB \\ Professor. Faculté des Sciences Economiques et de Gestion de Nabeul \\ Université du 7 novembre de Carthage. Tunisia \\ Email: ezzedine.abaoub@fsegt.rnu.tn
}

Received: January 01, 2013 Accepted: February 05, 2013 DOI: 10.5296/ijafr.v3i1.2978

\begin{abstract}
This paper empirically investigates the value relevance of accounting earnings measures in the emerging capital market of Tunisia. The issue is tested by estimating the regression of annual stock returns on different earnings measures extracted from income statements. In Tunisia, firms prepare their financial statements in accordance with Tunisian Accounting Standards (TAS) which are inspired from International Financial Reporting Standards (IFRS). Based on a sample of 389 firm year observations for firms listed on the Tunis Stock Exchange (TSE) during the period 1997-2008 and using pooled regressions, we find that accounting earnings measures are weakly related to stock returns. However, earnings before taxes have the higher explanatory power for stock returns. This is perhaps due to the fact that financial statements are often influenced by taxation rules (ROSC, 2006; Paragraph 42). Further, we find that cash flow from operations and total accruals are not value relevant for valuation. We tested whether the value relevance of each measure of performance improved after the adoption in October 2005 of the Law on Strengthening the Security of Financial Relations (LSSFR). Consistent with prior US and other international findings, results show that the explanatory power and the magnitude of the slope coefficient of each measure increased when we take into account for the impact of this enactment. However, the increase is not statistically significant. This is perhaps due to the employed specification of the relation between stock returns and accounting information.
\end{abstract}

Keywords: Earnings, stock returns, value relevance, explanatory power, slope coefficient. 


\section{Introduction}

Accounting earnings is considered as the most important variable to investors in financial markets because it allows them to have a good idea about firm performance and its capacity to pay dividends. The role of accounting earnings in security price setting has at the forefront of Accounting-based capital market research. Beginning with the seminal work of Ball and Brown (1968) who found an empirical relationship between earnings and stock returns, the last four decades of accounting research have produced a substantial volume of theoretical and empirical works on the relationship between stock returns (dependent variable) and accounting earnings (independent variable). Many researchers have conducted association studies to measure the intensity of the relation between the two variables. They used the slope coefficient (also, called earnings response coefficient) and/or the $R^{2}$ of returns/earnings regression as measures of the information contribution of earnings to investors. Results showed that the relation is weak. The explanatory power does not exceed 10\%. Lev (1989), Hayn (1995), Collins et al. (1997), Kothari (2001), Beaver (2002) and Beisland (2010) among others attributed this weak relationship between earnings measures and stocks returns to many factors including: $i$ ) the low quality of reported earnings; $i$ ) errors in measuring the expected component of accounting earnings, and iii) The return/earnings relation is affected by the effects of transitory components, losses, extreme observations in earnings variable.

To date, theoretical and methodological refinements aimed at improving the specifications of the returns/earnings relation have yielded very modest results in furthering our understanding of how and to what extent accounting earnings is value relevant. Most of the previous studies in this area have largely focused on US and UK stock markets and concluded that earnings measures are value relevant, but weakly associated to stock returns. This study investigates the value relevance of different accounting earnings measures in the Tunis Stock Exchange.

There are at least five motivations for this study. First, a growing number of papers focus on the usefulness of accounting information in transition and emerging countries (see Beisland, 2009 for literature review). These studies adopt value relevance methodology to test for the quality of accounting standards, accounting practices and local stock markets. Second, listed companies on the Tunis Stock Exchange (TSE) prepare their financial statements according to the Tunisian Accounting Standards which are inspired from the International Financial Reporting Standards (IFRS). This gives an idea about the quality of reported earnings and their usefulness. Third, the pricing of earnings components is of universal interest because Generally Accepted Accounting Principles (GAAP) around the world require reported earnings to be disaggregated into components in income statements. Hence, this study seeks to compare net income and different measures of earnings in terms of their relations with stock returns using Tunisian data, subsequent to the adoption of the Enterprise Accounting System (EAS) in December 1996. This allows assessing the quality of earnings components used in financial and profitability analyses. Fourth, since recent scandals of Enron, Worldcom in the USA and Batam in Tunisia, there are growing concerns among regulators and investors that financial statements are becoming increasingly unreliable as a source of information about firms' core operations and prospects. The allegation is that managers exploit the 


\section{Mll Macrothink}

International Journal of Accounting and Financial Reporting ISSN 2162-3082 2013, Vol. 3, No. 1

discretion permitted under the Generally Accepted Accounting Principles (GAAP) to manage financial reports in ways that hide or exaggerate the economic performance of firms (Kalelkar and Nwaeze, 2011, p 276). Fifth, as the Sarbanes-Oxley Act (SOX, hereafter) in the USA on July 30, 2002, and 'Loi de Sécurité Financière' (LSF) on First Août, 2003 in France and in other countries, Tunisia promulgated in October 2005 the Law on Strengthening the Security of Financial Relations (LSSFR, hereafter) to enhance the quality of disclosed accounting data and to restore investors' confidence in the integrity of accounting information. This study tests for any improvement in financial reporting in period post regulation. We use statistical association between accounting data and stock returns to assess the usefulness of financial information to investors and we focus on the explanatory power of models measured by $R^{2}$ and the magnitude of the slope coefficient.

The remainder of the paper is organized as follows: the next section presents a brief literature review on the impact of similar law enacted in the USA (the Sarbanes Oxley Act). Section 3 describes the financial reporting in Tunisia; Section 4 motivates the study and develops the hypotheses. Section 5 provides the estimated models and sample selection techniques. Section 6 discusses the empirical results, and section 7 concludes the paper.

\section{Literature review}

The enactment of the Sarbanes-Oxley Act in 2002 followed a series of highly publicized scandals that highlighted weaknesses in corporate financial reporting in USA (i.e., Enron, Ahold and WorldCom,...). Many studies focused on the impact of SOX on the quality of financial reporting. Mbagwu (2007) examined the impact of SOX in the American context. The author used two methodologies. First, a dummy variable "Post" that represents the period after the implementation of the Act and second by dividing the data set into pre- and post-SOX periods and running the regressions for each period separately. The author found an improvement of the value relevance of three earnings measures after the implementation of the SOX Act. Verleun et al. (2011) used earnings management, conservatism and value relevance measures in order to examine the impact of SOX on accounting quality. The analysis seeks evidence that SOX is associated with changes in investors' perception of earnings and accruals quality. However, on a sample of 4,000 firms for the years $2000-2005$, Wilson finds no evidence of increased earnings quality resulting from the SOX Act. Lobo and Zhou (2006) examined whether the enactment of SOX had an influence on the degree of conservatism in financial reporting. They found a significant increase in conservatism thus an increase in accounting quality after SOX. Cohen et al. (2005) found that earnings management increased during the period of the accounting scandals. However, after the passage of SOX, the degree of earnings management declined abruptly and significantly. $\mathrm{Ng}$ et al. (2007, p 6) state that investor confidence mainly depends on two factors- quality of internal control and adequacy of legal or regulatory environment to protect investors from misleading financial reports. In their view, investors believe a firm will not engage in earnings management if there is strong internal control and / or strong laws that will severely punish the firms for fraud. They find that investors treat stronger regulatory regime imposed by SOX as a near-perfect substitute for good internal governance. Under this logic, investors' perception of financial reporting quality can be expected to be stronger following SOX. 


\section{MInstitute Macrothink $_{\text {Int }}$}

International Journal of Accounting and Financial Reporting ISSN 2162-3082 2013, Vol. 3, No. 1

On a sample of 9527 firm-year observations and using pre-SOX period as the control period, Kalelkar and Nwaeze (2011) regressed returns on earnings and earnings components, augmented with interactions of earnings components with SOX indicator. In addition, they controlled for the effects of firm size, growth, earnings volatility, leverage, risk, Enron failure, and loss on the returns-earnings relation. Authors found significant increases in the valuation weights of earnings, cash-flow from operations and total accruals after the passage of SOX. When they separated total accruals into non- discretionary and discretionary components, they found a significant increase in the weight of the discretionary component and found mixed results for non-discretionary accruals. In sum, there are reports of improvement in the quality of financial reports in general and of earnings, in particular after SOX in USA (Kalelkar and Nwaeze, 2011).

Beisland (2010) examined the effect of the Norwegian Act of 1998 on the value relevance of earnings. Results show that the value relevance of earnings increased after disaggregating earnings on its components accruals and cash flows and after taking into account the sign of earnings. The author added that these results are dependent upon the regression specification being employed.

\section{Financial reporting in Tunisia}

Until 1996, there were many differences between Tunisian Accounting Standards (TAS) and International Accounting Standards (IAS). Tunisian Accounting Standards changed dramatically on January 1, 1997, when the Law on the Enterprise Accounting System (EAS, hereafter) became effective. The EAS provides for establishment of the National Accounting Council (NAC, hereafter), which is an advisory body to the Ministry of Finance. The NAC's (which took over from the Supreme Council of Accounting, created in 1975) mandate specifically encompasses the following tasks: review and opine on draft accounting standards including modalities for their application and accounting matters set out in draft laws and regulations.

The EAS contains a Tunisian Accounting Conceptual Framework and Tunisian Accounting Standards. The Tunisian framework which is largely based on IASB's Framework for the Preparation and Presentation of Financial Statements sets out the concepts that underlie the preparation and presentation of financial statements for external users. The Tunisian Accounting Standards which are inspired from IFRS are enacted by Orders issued by the Minister of Finance. The membership of the Council embodies a wide array of stakeholders: the Minister of Finance; the Governor of the Central Bank (or their respective designate); representatives from different ministries with an interest in accounting matters; the supreme audit institution, the accounting and audit profession, and the relevant regulators. The adoption of EAS has introduced considerable change in Tunisian accounting practice affecting the recognition and measurement of assets, liabilities and profit. In December 1996, fifteen accounting standards have been issued by the NAC.

Since 1996, a lot of hard work is done by stock market regulators and accounting standards setters in improving the quality of financial reporting and increasing the transparency level in financial reporting. In 1999, the NAC have issued specific accounting standards for 


\section{Mll Macrothink}

International Journal of Accounting and Financial Reporting ISSN 2162-3082 2013, Vol. 3, No. 1

Undertakings for Collective Investment (TAS 16 to 18) and specific credit institution accounting standards (TAS 21 to 25) which are supplemented by Central Bank of Tunisia Regulations. Accounting standards related to Interim financial statements (TAS 19) and Research and Development (TAS 20) are also issued in the same year. In 2000, specific insurance accounting standards (TAS 27 - 31) have been issued. Tunisia enacted TAS 35, Consolidated Financial Statements, in 2003. TAS 35 is largely based on IAS 27, Consolidated Financial Statements and Accounting for Investments in Subsidiaries. Standard on accounting for leases (TAS 41) has been issued in 2008. Finally, simplified accounting standard (TAS 42) has been recently issued.

In October 2006, the World Bank and the International Monetary Fund (IMF) have prepared a report (final version) about the assessment of accounting and auditing practices in Tunisia (Report on the Observance of Standards and Codes: 'ROSC'). The assessment focused on the strengths and weaknesses of the accounting and auditing environment that influence the quality of corporate financial reporting. The ROSC documented that changes in Tunisian Accounting Standards can generally be considered to have been a massive step toward harmonization with IFRS which contributed to enhanced transparency. However, some fundamental differences remain, and TASs, are seriously flawed and are not adapted to modern securities market transparency requirements, and do not provide the general public with sufficient information about firms and still impede reliability and comparability. Selected differences between IFRS and TAS include the following: $i$ ) consolidation reporting requirements fall short of IAS, ii) TASs do not require that information be reported for business segments and geographical segments, iii) TASs do not mention differed tax accounting as in IAS 12 and $i v$ ) TAS have no equivalent rules to International Standards regarding financial instruments.

The ROSC team made assessments of the compliance gap of financial statements prepared in accordance with TASs. The assessments revealed that financial statements are often influenced by taxation rules (Paragraph 42). To satisfy requirements of taxation authorities with regard to recognition of revenues and expenses, preparers of financial statements tend to follow tax rules rather than the accounting treatment required by TAS in various areas (e.g., depreciation, revenue recognition, provisions). The ROSC team concluded that transparency suffers from this emphasis on tax and deviation from applicable financial reporting standards.

Finally, the report documented other significant issues which may raise questions about the quality of the statutory audit and in consequence the quality of accounting information including: i) until December 2003, consolidated financial statements were not presented, which has an adverse impact on the transparency of financial reporting; ii) accounting policies are not disclosed, and iii) earnings per share are not disclosed. Failure to disclose such information is particularly a concern with respect to listed companies.

The report concluded that compliance with accounting requirements in Tunisia is not always effectively and consistently enforced due to deficiencies in the three core pillars of any enforcement regime, i.e., management, statutory auditors, and regulators. (i. e., The Financial Market Council seeks to enforce accounting standards in general purpose financial statements 


\section{MInstitute ${ }^{m+1}$ Macrothink}

International Journal of Accounting and Financial Reporting ISSN 2162-3082

of companies raising funds from the public but does not consistently demand restatement of accounting issues it discovers or impose sanctions on offenders). Further, managers and auditors do not consistently comply with accounting and auditing requirements, which adversely impact the usefulness of accounting information.

The recent collapse of BATAM, quoted in Tunisian capital market, and the irregularities found in its accounting statements have brought to sharp focus the role of the external auditor. BATAM has now become a byword for bad management and auditing, after being placed under judicial administration in October 2002 for defaulting on approximately $\$ 220 \mathrm{~m}$ of debts. This affair constitutes the first crisis of the Tunisian capitalism, which put in evidence a plurality of responsibility in particular that of the auditor which was imprisoned because he has not revealed the accounting irregularities. The affair of this company on 2002 and 2003 caused a decrease of portfolio value for small investors, not being protected in this date.

It should be noted that a new Law on Strengthening the Security of Financial Relations was passed in October (2005) to reinforce the role of the Financial Market Board in the exercise of its mission and to enhance the transparency and quality of financial statements.

In order to reinforce the independence of the companies' statutory auditors, the law stipulated principles dealing with rotation, misdemeanour, obligatory invitation of the statutory auditors to the board meetings and to the general assembly meetings, confirmation letter, and the co-statutory auditors. In case of co-statutory auditors, the same law stipulates that the statutory auditors should be fully independent. In case of noncompliance, a process is put in place to ensure full respect of the law and to discipline the failed auditors.

The law established sanctions and penalties for managers and chief financial officer for providing to the statutory auditors inaccurate or incomplete information about the activities of the company or obstructing the work of auditors in the course of their missions. These sanctions include a six months of imprisonment and/or fine of 5000 dinars. The severe consequences for falsely attesting to firm financial statements may reduce management's incentive to manipulate reported earnings in an attempt to reach earnings targets. The primary goal of these provisions was to improve the quality of corporate financial reporting and to restore investors' confidence in the integrity of accounting information. As result, firms increased voluntary disclosure of their information security activities in the post-LSSFR periods. Aside from their six monthly and annual financial statements, listed companies began in 2006 to publish indicators of quarterly activity, in application of the terms of article of law $n^{\circ} 2005-96$ of 18 October 2005 concerning enhanced security measures for financial relations.

\section{Hypotheses}

According to our synthesis of the literature made on factors affecting the value relevance of accounting information and more precisely the impact of some laws enacted to improve the quality of financial reporting in the USA, and basing on the assessment of accounting and auditing practices in Tunisia made in 2006, it would be interesting to examine the value relevance of different earnings measures in Tunisian context and to analyze the impact of the 
enactment of the law $\mathrm{n}^{\circ} 2005-96$ of 18 October 2005 on strengthening the security of financial relations on the value relevance of accounting information in general and of earnings based accruals in particular.

\section{Hypothesis 1: There is a weak, but significant relation between stock returns and earnings measures}

The first hypothesis predicts that earnings measures have a weak association with stock returns. There are at least two motivations for testing this hypothesis:

i) The lack of existing research on the value relevance of accounting information in Tunisian context. Thus, this study contributes to an understanding of value relevance in light of the Tunis Stock Exchange's evolution, and

ii) The link of TAS to (IAS/IFRS) standards and to inform investors and regulators in Tunisia about the value relevance of accounting information in the TSE.

\section{Hypothesis 2: Returns/earnings relationship is improved after the adoption in October 2005 of the Law on Strengthening the Security of Financial Relations (LSSFR)}

There are at least two motivations for testing this hypothesis. First, there is a strong evidence that the returns/earnings relation is not stable over time. Hence, earlier studies documented:

i) a decline in the value relevance of accounting information over time (Collins et al, 1997; Lev and Zarowin, 1999; Ely and Waymire, 1999; Francis and Schipper, 1999; Brown et al, 1999 in USA ; Easton et al, 2000 in the Australian context) ;

ii) an increasing value relevance after the implementation of some acts (Kalelkar and Nwaeze, 2011 in USA; Beisland, 2010 for a sample of Norwegian firms, Gjerde, 2005).

The second motivation stems from the view that standard setting bodies and regulators seek to enhance the relevance of accounting data to financial statements users.

\section{Methodology of the Study}

Previous studies such as those of Verleun et al. (2011) used earnings management, conservatism and value relevance measures to examine the impact of SOX Act in the American context. In our context, we use the value relevance measure. However, one serious problem of measuring value relevance is that this metric relies on market information. Thus, if the market is highly inefficient a value relevance assessment could result in the conclusion that accounting quality is low while this is not the case. Therefore an implicit assumption for this measure to be valuable is that markets are to a certain extent efficient. Barth (2000, p 11) suggests that even if the market is not totally efficient in processing the valuation implications of all publicly available information, share prices reflect the consensus beliefs of investors. Thus, share prices have become the most common value measure used in financial reporting research.

\subsection{Sample}

The basic sample consists of all firm-years for which earnings data are available on the Tunis 


\section{Mll Macrothink}

International Journal of Accounting and Financial Reporting ISSN 2162-3082 2013, Vol. 3, No. 1

Stock Exchange (TSE) database. It contains 489 firm years over the 12-year period 1997-2008, representing 54 distinct firms listed on the TSE. Return information is retrieved from the Financial Market Council database. Certain analyses impose data requirements, such as availability of sufficient return data and minimal number of years with consecutive earnings data that result in a reduction of the number of firm-years. The final sample consisted of 389 firm-year observations. We use all observations, including extreme values of accounting measures and stock returns, because in tests comparing the stability of the relationship between stock returns and earnings measures, the extreme observations could be very important (Das and Lev, 1994; Freeman and Tse, 1992). The variables used in the present study are defined as follows:

- Stock return (RET): Annual stock return for the fiscal year calculated according to the following equation:

$\operatorname{RET}_{t}=\left[\left(P_{t}-P_{t-1}\right)+D_{t}\right] / P_{t-1}$

Where $\left(P_{t}-P_{t-1}\right)$ is the change in share price in the fiscal year, $D_{t}$ is dividends paid per share; and $P_{t-1}$ is share price at the beginning of the fiscal year.

We have used five measures firm performance (operating earnings, earnings before taxes, net income, cash flows from operations and total accruals):

- Operating earnings (OP): defined as earnings before non-operating items, exceptional and extraordinary items. It captures the results of the firms' ongoing operations that will likely recur in the future. This measure is used by Ely and Waymire (1999), Charitou et al. (2001).

- Earnings before taxes (E-TAX): Operating earnings (OP) adjusted for other items (other gains and losses, interest expenses). This measure is used by Dechow (1994).

- Net income (NI): defined as ordinary earnings after taxes, adjusted for extraordinary items;

- Cash flows from operations (CFO):

- Total accruals (ACC): corresponds to the difference between net income (NI) and Cash flows from operations (CFO).

All variables used in the empirical tests are divided by the year-end number of shares and scaled by the beginning-of-period share price.

In Table 1, we present summary statistics for all variables used in the regression models for the pooled observations (Panel A) and for observations in the pre-LSSFR (Panel B) and post-LSSFR periods (Panel C). Descriptive statistics results indicate that:

(i) The magnitude of operating earnings is higher than that of earnings before taxes and net income. This indicates that other items and taxes are decreasing income. The mean of these components are negative in all periods.

(ii) The mean of CFO (accruals) are positive (negative) during the two periods. Negative values for the mean are consistent with evidence in prior studies (Barth et al., 2001, p37), and are chiefly attributable to the negative effect of noncurrent accruals (e.g., depreciation 
and amortization of long-term assets). Further, the standard deviation for net income is less than the standard deviations for both cash flows and accruals. This indicates that accruals, to a certain extent, level out cash flow fluctuations and/or, managers may use accruals to reduce the magnitude of net income. These results are consistent with evidence in prior studies (Beisland, 2010, p 3). Moreover, total accruals are more decreasing earnings prior to LSSFR.

(iii) Operating earnings, earnings before taxes and net income are on average more positive in pre-LSSFR period than in post-LSSFR period. One may interpret the lower magnitude of each earnings measure as evidence for more conservatism.

(iv) The standard deviation of CFO and accruals for the first period are higher than those of the second period.

(v) Taxes are more income-decreasing in the pre LSSFR period.

Verleun et al. (2011), basing on the hypothesis of market efficiency, suggested that when investors expect a law relating to strengthening the financial relations to be beneficial and thus value increasing there should be positive abnormal returns related to specific important SOX related events. Consistent with Verleun et al. (2011), in the Tunisian context, the mean of stock returns during the period 1997-2004 (0.126) is positive and lower than its value in the period preceding the adoption of the LSSFR (0.191).

Jain and Rezaee (2006) and Li et al. (2008) investigate investors' reactions to SOX. They predict that if investors believe SOX will reduce earnings management, there will be positive abnormal return at the passage of the Act. Both studies detect positive abnormal returns at the passage of SOX, indicating that investors view the Act favorably. Consistent with these findings, we find that the proportion of positive stock returns, measured by the ratio (Positive returns/Positive and negative returns) for first sub-period is $(119 /(119+55))=68,4 \%$ higher than its value for the second sub-period $(117 /(98+117)=$ $54,4 \%$ ), which presume that investors view the law favorably.

In order to examine whether the difference in mean of variables is statistically significant $t$-tests are conducted (see Table 1: Panel D). Results show that the mean differences are not statistically significant for each earnings measure (OP, E-TAX and NI). However, the differences are statistically significant for CFO, accruals, taxes and other items. Total accruals are on average, more positive in post-LSSFR periods than in pre LSSFR period. Further, taxes and other items are increasing income in post LSSFR period. 


\section{Macrothink}

International Journal of Accounting and Financial Reporting ISSN 2162-3082 2013, Vol. 3, No. 1

Table 1. Descriptive statistics of different earnings components in pre- and post-LSSFR periods for different sample compositions

\begin{tabular}{|c|c|c|c|c|}
\hline Variable & Mean & Std. dev. & Min & Max \\
\hline \multicolumn{5}{|l|}{ Panel A $(\mathrm{N}=389)$ : Full sample $\quad(1997-2008)$} \\
\hline RET & 0.155 & 0.429 & -0.656 & 3.068 \\
\hline Positive RET (236 firm year observations) & 0.367 & 0.423 & 0.004 & 3.068 \\
\hline Negative RET (153 firm year observations) & -0.171 & 0.126 & -0.656 & -0.001 \\
\hline $\mathrm{OP}$ & 0.077 & 0.233 & -1.702 & 0.693 \\
\hline E-TAX & 0.051 & 0.245 & -1.666 & 0.446 \\
\hline NI & 0.034 & 0.240 & -1.684 & 0.338 \\
\hline $\mathrm{CFO}$ & 0.320 & 0.964 & -1.658 & 9.339 \\
\hline $\mathrm{ACC}$ & -0.286 & 1.005 & -9.944 & 1.750 \\
\hline Tax & -0.017 & 0.016 & -0.161 & 0.001 \\
\hline Extra & -0.000 & 0.001 & -0.013 & 0.013 \\
\hline Others & -0.025 & 0.112 & -1.040 & 0.474 \\
\hline \multicolumn{5}{|c|}{ Panel B $\quad(\mathrm{N}=215):$ Before the adoption of LSSFR $(1997-2004)$} \\
\hline RET & 0.126 & 0.479 & -0.656 & 3.068 \\
\hline Positive RET $\left(\mathrm{N}_{1}=117\right)$ & 0.379 & 0.519 & 0.004 & 3.068 \\
\hline Negative RET $\left(\mathrm{N}_{2}=98\right)$ & -0.175 & 0.126 & -0.656 & -0.001 \\
\hline $\mathrm{OP}$ & 0.093 & 0.254 & -1.702 & 0.693 \\
\hline E-TAX & 0.058 & 0.236 & -1.666 & 0.446 \\
\hline NI & 0.039 & 0.229 & -1.684 & 0.301 \\
\hline $\mathrm{CFO}$ & 0.441 & 1.112 & -1.421 & 9.339 \\
\hline $\mathrm{ACC}$ & -0.402 & 1.158 & -9.944 & 1.567 \\
\hline Tax & -0.018 & 0.018 & -0.161 & 0.001 \\
\hline Extra & 0.000 & 0.000 & -0.002 & 0.005 \\
\hline Others & -0.035 & 0.116 & -0.552 & 0.474 \\
\hline \multicolumn{5}{|c|}{ Panel $C(\mathrm{~N}=174)$ : After the adoption of LSSFR $(2005-2008)$} \\
\hline RET & 0.191 & 0.355 & -0.577 & 1.491 \\
\hline Positive RET $\left(\mathrm{N}_{3}=119\right)$ & 0.355 & 0.303 & 0.005 & 1.491 \\
\hline Negative RET $\left(\mathrm{N}_{4}=55\right)$ & -0.163 & 0.128 & -0.577 & -0.004 \\
\hline $\mathrm{OP}$ & 0.056 & 0.204 & -1.149 & 0.394 \\
\hline E-TAX & 0.043 & 0.257 & -1.481 & 0.347 \\
\hline NI & 0.028 & 0.253 & -1.486 & 0.338 \\
\hline $\mathrm{CFO}$ & 0.171 & 0.717 & -1.658 & 5.008 \\
\hline $\mathrm{ACC}$ & -0.142 & 0.754 & -4.852 & 1.750 \\
\hline Tax & -0.015 & 0.014 & -0.065 & 0.000 \\
\hline Extra & -0.000 & 0.001 & -0.013 & 0.013 \\
\hline Others & -0.012 & 0.107 & -1.040 & 0.195 \\
\hline
\end{tabular}


Panel D. Comparison of mean earnings measures between pre- and post-LSSFR periods

\begin{tabular}{|l|c|c|c|}
\hline Variable & $\begin{array}{c}\text { Mean difference } \\
\text { pre-LSSFR-post-LSSFR) }\end{array}$ & T-test for Equality of Means & $p$-value \\
\hline OP & 0.037 & 1.5626 & 0.059 \\
\hline E-TAX & 0.014 & 0.5683 & 0.285 \\
\hline NI & 0.010 & 0.4418 & 0.329 \\
\hline CFO & 0.269 & 2.7690 & $0.002^{* * *}$ \\
\hline ACC & -0.259 & -2.5461 & $0.005^{* * *}$ \\
\hline Tax & -0.003 & -2.0599 & $0.020^{* *}$ \\
\hline Others & -0.022 & -1.9994 & $0.023^{* *}$ \\
\hline Extra & 0.000 & 0.4577 & 0.323 \\
\hline
\end{tabular}

RET: Stock returns, $O P$ : operating earnings, E-TAX: Earnings before taxes, NI: net income; CFO: Cash flows from operations, ACC: Total accruals, Tax: taxes; Extra: Extraordinary items. Others: the difference between earnings before taxes and operating earnings. All accounting variables are deflated by beginning-period market value of equity to be consistent with the returns variable.

Table 2 presents the Pearson and Spearman correlations between the variables used in regressions. Results indicate that $(i)$ there is a positive and statistically significant correlation between all earnings measures and stock returns and (ii) the Pearson correlation between stock returns and earnings before taxes (0.238) is greater than that with other earnings measures. The correlations between cash flows from operations and stock returns are not statistically significant.

Table 2. Correlation matrix $(N=389)$

\begin{tabular}{|l|c|c|c|c|c|c|c|c|c|}
\hline & RET & OP & E-TAX & NI & CFO & ACC & Tax & Extra & Others \\
\hline RET & 1 & $0.30^{* * *}$ & $0.43^{* * *}$ & $0.44^{* * *}$ & 0.05 & $0.12^{* *}$ & $-0.26^{* * *}$ & 0.02 & $0.11^{* * *}$ \\
\hline OP & $0.19^{* * *}$ & 1 & $0.85^{* * *}$ & $0.84^{* * *}$ & $0.27^{* * *}$ & 0.01 & $-0.64^{* * *}$ & 0.06 & $-0.23^{* * *}$ \\
\hline E-TAX & $0.23^{* * *}$ & $0.89^{* * *}$ & 1 & $0.98^{* * *}$ & $0.27^{* * *}$ & 0.06 & $-0.69^{* * *}$ & 0.05 & $0.13^{* * *}$ \\
\hline NI & $0.22^{* * *}$ & $0.88^{* * *}$ & $0.99^{* * *}$ & 1 & $0.26^{* * *}$ & 0.07 & $-0.59^{* * *}$ & 0.05 & $0.13^{* * *}$ \\
\hline CFO & 0.01 & 0.06 & -0.03 & -0.05 & 1 & $-0.85^{* * *}$ & $-0.20^{* * *}$ & -0.01 & 0.06 \\
\hline ACC & 0.03 & $0.15^{* * *}$ & $0.27^{* * *}$ & $0.28^{* * *}$ & $-0.97^{* * *}$ & 1 & -0.00 & 0.01 & $0.12^{* *}$ \\
\hline Tax & $-0.34^{* * *}$ & $-0.39^{* * *}$ & $-0.37^{* * *}$ & $-0.31^{* * *}$ & $-0.13^{* * *}$ & 0.05 & 1 & -0.06 & -0.05 \\
\hline Extra & 0.01 & 0.05 & 0.02 & 0.02 & -0.00 & 0.00 & -0.07 & 1 & -0.06 \\
\hline Others & $0.10^{* *}$ & $-0.13^{* *}$ & $0.33^{* * *}$ & $0.34^{* * *}$ & -0.21 & $0.28^{* * *}$ & -0.00 & -0.05 & 1 \\
\hline
\end{tabular}

***, *** and *: Pearson (Spearman) correlation are below (above) the diagonal significant at $10 \%, 5 \%$ and $1 \%$ level, respectively. 


\section{MlMacrothink}

International Journal of Accounting and Financial Reporting

\subsection{Benchmark models}

Initially, we estimate benchmark models that relate earnings and its components to returns to provide a baseline for testing our main hypotheses.

$$
\begin{aligned}
& \mathrm{M}_{1 \mathrm{a}}: \mathrm{RET}_{i t}=\alpha_{0}+\alpha_{1} \mathrm{OP}_{i t}+e_{i t} \\
& \mathrm{M}_{2 \mathrm{a}}: \mathrm{RET}_{i t}=\alpha_{0}+\alpha_{1} \mathrm{E}_{-\mathrm{TAX}}+e_{i t} \\
& \mathrm{M}_{3 \mathrm{a}}: \mathrm{RET}_{i t}=\alpha_{0}+\alpha_{1} \mathrm{NI}_{i t}+e_{i t} \\
& \mathrm{M}_{4 \mathrm{a}}: \mathrm{RET}_{i t}=\alpha_{0}+\alpha_{1} \mathrm{CFO}_{i t}+e_{i t} \\
& \mathrm{M}_{5 \mathrm{a}}: \mathrm{RET}_{i t}=\alpha_{0}+\alpha_{1} \mathrm{ACC}_{i t}+e_{i t}
\end{aligned}
$$

Where, $\alpha_{0}$ is the intercept term; $\alpha_{1}$ : the slope coefficient, and $e_{i t}$ is the error term. In these models, we control for the magnitude, respectively of the slope coefficient values $\left(\alpha_{1}\right)$ and the explanatory power of the model, measured by $R^{2}$ (or adjusted $R^{2}$ ).

The first hypothesis is examined by performing five pooled regressions: (1) stock returns on operating earnings, (2) stock returns on earnings before taxes, (3) stock returns on net income, (4) stock returns on cash flows from operations, and (5) stock returns on total accruals. The paper compares each measure's association with stock returns considered as the benchmark measure of firm performance (Dechow, 1994: p 21) and judges the one with the highest to be a more useful measure of firm performance.

\section{Empirical results}

\subsection{Primary results}

This sub-section discusses the empirical results that relate to the tests of the research hypotheses. Results of pooled estimation of benchmark models are presented in Table 3. For each model, the estimated intercept, earnings slope coefficient, and adjusted $R^{2}$ are reported.

The adjusted $R$-square of the first model $\left(\mathrm{M}_{1 \mathrm{a}}\right)$ using operating earnings (OP) as independent variable is $3.70 \%$ and the slope coefficient of this variable is positive $\left(\alpha_{1}=0.365\right)$ and statistically significant at the 0.01 level. Results indicate that operating earnings is value relevant but appears to explain only weakly the variation of share return (adjusted $\left.R^{2}<5 \%\right)$. The adjusted $R^{2}$ of the second model $\left(\mathrm{M}_{2 \mathrm{a}}\right)$ using earnings before taxes (E-TAX) as explanatory variable is $5.46 \%$ and the regression coefficient is 0.417 (statistically significant at the 0.01 level). There is a substantial increase in explanatory power and in the coefficient. These results are consistent with the conclusion made by the ROSC (2006: paragraph 42) that "financial statements are often influenced by taxation rules" and "transparency suffers from this emphasis on tax and deviation from applicable financial reporting standards". Note that in Tunisia, there is a difference between earnings before taxes and taxable income. This suggests that the market attaches value to earnings before taxes and that managers manipulate some earnings components to report an earnings number before paying taxes which is more value relevant than the other components of income statements. 
Table 3. Regression results of the association of each measure of performance with stock returns (measured over the fiscal year period) for a sample of 389 firm-year observations during the period 1997-2008

\begin{tabular}{|c|c|c|c|c|c|c|c|c|}
\hline Models & Intercept & $\mathrm{OP}$ & E-TAX & NI & $\mathrm{CFO}$ & $\mathrm{ACC}$ & $R_{a}^{2} \%$ & $F$-Value \\
\hline $\mathrm{M}_{1 \mathrm{a}}$ & $\begin{array}{c}0.127 * * * \\
(5.93) \\
{[6.02]}\end{array}$ & $\begin{array}{c}0.365 * * * \\
(4.02) \\
{[4.19]}\end{array}$ & & & & & 3.70 & $\begin{array}{c}16.18 * * * \\
(0.0001) \\
17.56 * * *\end{array}$ \\
\hline $\mathrm{M}_{2 \mathrm{a}}$ & $\begin{array}{c}0.133 * * * \\
(6.30) \\
{[6.36]}\end{array}$ & & $\begin{array}{c}0.417 * * * \\
(4.55) \\
{[4.94]}\end{array}$ & & & & 5.46 & $\begin{array}{c}20.73 * * * \\
(0.0000) \\
24.45 * * * \\
\end{array}$ \\
\hline $\mathrm{M}_{3 \mathrm{a}}$ & $\begin{array}{c}0.141 * * * \\
(6.67) \\
{[6.62]}\end{array}$ & & & $\begin{array}{c}0.394 * * * \\
(4.56) \\
{[5.04]}\end{array}$ & & & 4.62 & $\begin{array}{c}20.79 * * * \\
(0.0000) \\
25.44 * * *\end{array}$ \\
\hline $\mathrm{M}_{4 \mathrm{a}}$ & $\begin{array}{c}0.153 * * * \\
(6.78) \\
{[6.44]}\end{array}$ & & & & $\begin{array}{l}0.007 \\
(0.40) \\
{[0.40]} \\
\end{array}$ & & -0.23 & $\begin{array}{c}0.16 \\
(0.6868) \\
0.16 \\
\end{array}$ \\
\hline $\mathrm{M}_{5 \mathrm{a}}$ & $\begin{array}{c}0.159 * * * \\
(7.10) \\
{[6.74]}\end{array}$ & & & & & $\begin{array}{l}0.016 \\
(0.85) \\
{[0.89]} \\
\end{array}$ & -0.11 & $\begin{array}{c}0.72 \\
(0.3966) \\
0.80 \\
\end{array}$ \\
\hline
\end{tabular}

${ }^{* * *}=$ statistically significant at $a=0.01$. OP: operating earnings, E-TAX: Earnings before taxes, NI: Net income, CFO: Cash flows from operations, ACC: Total accruals, RET: Stock return. All accounting measures used in the empirical models were deflated by the security price of the firm at the beginning of the fiscal year (i.e.: $\left.P_{i t-l}\right)$. White's (1980) heteroscedasticity -corrected $t$-statistics are presented in parentheses below the coefficients which assume that the residuals of the estimated equation are serially uncorrelated. However, where both heteroscedasticity and autocorrelation of unknown form has been encountered, Newey and West (1987) standard errors have been used and corrected $t$-statistics are shown in brackets.

These findings are consistent with Dechow (1994) documenting an adjusted $R^{2}$ of earnings before taxes about $6.34 \%$ for annual return interval. Results of estimating the third model $\left(\mathrm{M}_{3 \mathrm{a}}\right)$ show that the adjusted $R$-square using net income (NI) as independent variable is $4.62 \%$ and the regression coefficient is 0.394 (significant at the 0.01 level). As expected, the coefficient on each earnings measure is positive and statistically significant. The coefficients on cash-flow and total accruals are both positive but are not statistically significant.

The weak magnitude of earnings slope coefficient is perhaps due to the fact that independent variable consists of a value-relevant and a value-irrelevant component. The former is assumed to be perfectly correlated with stock returns, whereas the latter "noise" is uncorrelated with stock returns. In the presence of value-irrelevant noise in earnings, the independent variable is measured with error and return specification yields downward-biased earnings slope coefficient (Kothari and Zimmermann, 1995: p163). Further, all models yield highly significant intercept estimates. The intercept of 0.142 (significant at 


\section{MlMacrothink}

International Journal of Accounting and Financial Reporting ISSN 2162-3082 2013, Vol. 3, No. 1

the $1 \%$ level) represents the part of return that is not captured in accounting earnings. A nonzero intercept implies that the slope coefficient is biased, which indicates either model specification problems or an omitted-variables problem (Kothari and Zimmerman, 1995).

There are also other reasons explaining the weak relationship between stock returns and earnings. First, the affair of Batam (the accounting scandal occurred in 2002 which arose in part from weaknesses and deficiencies identified in accounting and auditing practices) had a very negative impact on the perception of users of audited financial statements. Second, it should be noted that accounting data for year $t$ are announced in the first quarter of the year $t+1$, so stock returns for the year $t$ reflect investor's expectations revisions about future earnings before such earnings are announced. Consistent with Lev (1989), unexpected earnings, at the time of announcement might convey only a small part of the total information in earnings and the relationship between earnings and stock returns will not be seriously affected by the magnitude of announced earnings. Third, Tunisian Accounting Standards focus on investors needs but are determined by the government and net income is distributed amongst stakeholders, as pay increases to employees, bonuses to managers, tax to government, and dividends to shareholders. Fourth, in Tunisia, traditionally, banks play a key role in providing finance which may reduces the need for relevant and timely public disclosure of income. Also, the incentives (e.g., minimizing taxes and the opportunities to reinvesting earnings) to reduce earnings volatility exist in Tunisia which results in smoother patterns of dividend distributions which are linked to reported earnings.

In sum, results support the Hypothesis 1 and are consistent with US and other international findings showing a weak relationship between earnings and stock returns (Lev, 1989; Kothari, 2001; Dumontier and Raffournier, 2002, Beisland, 2010 and Veith and Werner, 2010).

\subsection{The impact of the promulgation of the Law on Strengthening the Security of Financial Relations 'LSSFR'}

In this sub-section, the possibility that the informativeness of the earnings measures may be affected by the implementation of the LSSFR Act is examined by using two approaches.

\subsubsection{First approach}

We test the impact of the LSSFR on the value relevance of accounting information by dividing the sample in a pre- and post-LSSFR period. The LSSFR was enacted October 18, 2005, thus all observations after this date are classified as post-LSSFR. This hypothesis is tested by comparing the explanatory power and the regression coefficient of all returns-earnings regressions before and after the period of regulation 2005 . If the LSSFR limits the ability of managers to manipulate earnings, then in the post LSSFR period, it is expected that earnings will be more associated with stock returns. Table 4 reports the results of estimating all earnings/returns regressions before and after the adoption of the LSSFR.

Results show that the association between stock returns and earnings measures, as measured by adjusted $R^{2}$, has been increasing throughout the 1997-2008 period: from 1,57\%-2.45\% in the first period (1997-2004) to $R^{2}$ s of $10.34 \%-12.57 \%$ in the post LSSFR period (2005-2008). 


\section{I Macrothink}

International Journal of Accounting and Financial Reporting ISSN 2162-3082 2013, Vol. 3, No. 1

The earnings slopes have been increasing, from a range of $0.27-0.34$ in the first period to 0.49-0.57 for the post regularly period. However, a Chow test for changes in the slope coefficient indicates stability over time of the returns/earnings relation. Hence, our evidence provides support (but not significantly) for the hypothesis that earnings relevance is higher and that there has been a change in the information environment following the adoption of the LSSFR which is consistent with the findings of Mbagwu (2007), Kalelkar and Nwaeze (2011) in USA and Beisland (2010) in the Norwegian context.

Table 4. Results of Hypothesis Tests for Increased Earnings Measures Relevance after the adoption of the Law on Strengthening the Security of Financial Relations

\begin{tabular}{|c|c|c|c|c|c|c|c|c|c|}
\hline \multicolumn{10}{|c|}{ Estimated Model: $\mathrm{RET}_{i t}=a_{0}+a_{1} \mathrm{E}_{i t}+e_{i t}$} \\
\hline & \multicolumn{4}{|c|}{ Panel A $(\mathrm{N}=215)$} & \multicolumn{4}{|c|}{ Panel B $(\mathrm{N}=174)$} & \\
\hline & \multicolumn{4}{|c|}{$\begin{array}{l}\text { Before the adoption of LSSFR } \\
\qquad(1997-2004)\end{array}$} & \multicolumn{4}{|c|}{$\begin{array}{l}\text { After the adoption of LSSFR } \\
\qquad(2005-2008)\end{array}$} & \\
\hline Variable & Intercept & $a_{1}$ & $R_{a}^{2} \%$ & F-Fisher & Intercept & $a_{1}$ & $R_{a}^{2} \%$ & F-Fisher & $\begin{array}{c}\text { Chow- } \\
\text { test } \\
p \text {-Value }\end{array}$ \\
\hline OP & $\begin{array}{l}0.100^{* * *} \\
(3.04)\end{array}$ & $\begin{array}{l}0.27^{* *} \\
(2.25)\end{array}$ & 1.69 & $\begin{array}{c}5.07^{* *} \\
(0.0254)\end{array}$ & $\begin{array}{l}0.158^{* * *} \\
(6.10)\end{array}$ & $\begin{array}{l}0.57^{* * *} \\
(4.38)\end{array}$ & 10.34 & $\begin{array}{l}19.15^{* * *} \\
(0.0000)\end{array}$ & 0.71 \\
\hline E-TAX & $\begin{array}{l}0.106^{* * *} \\
(3.21)\end{array}$ & $\begin{array}{l}0.34^{* *} \\
(2.17)\end{array}$ & 2.45 & $\begin{array}{l}4.70^{* *} \\
(0.0313)\end{array}$ & $\begin{array}{l}0.169^{* * *} \\
(6.86)\end{array}$ & $\begin{array}{l}0.49^{* * * *} \\
(6.08)\end{array}$ & 12.57 & $\begin{array}{l}36.98^{* * *} \\
(0.0000)\end{array}$ & 0.54 \\
\hline NI & $\begin{array}{l}0.114^{* * *} \\
(3.49)\end{array}$ & $\begin{array}{l}0.29^{* *} \\
(2.02)\end{array}$ & 1.57 & $\begin{array}{c}4.07^{* *} \\
(0.0448)\end{array}$ & $\begin{array}{l}0.176^{* * *} \\
(7.12)\end{array}$ & $\begin{array}{l}0.49^{* * *} \\
(6.04)\end{array}$ & 12.11 & $\begin{array}{l}36.44^{* * *} \\
(0.0000)\end{array}$ & 0.57 \\
\hline $\mathrm{CFO}$ & $\begin{array}{l}0.122^{* * *} \\
(3.49)\end{array}$ & $\begin{array}{l}0.007 \\
(0.37)\end{array}$ & -0.4 & $\begin{array}{c}0.13 \\
(0.7148)\end{array}$ & $\begin{array}{l}0.187^{* * *} \\
(6.93)\end{array}$ & $\begin{array}{l}0.024 \\
(0.76)\end{array}$ & -0.003 & $\begin{array}{c}0.58 \\
(0.4474)\end{array}$ & 0.76 \\
\hline $\mathrm{ACC}$ & $\begin{array}{l}0.128^{* * * *} \\
(3.67)\end{array}$ & $\begin{array}{l}0.004 \\
(0.21)\end{array}$ & -0.4 & $\begin{array}{c}0.04 \\
(0.8347)\end{array}$ & $\begin{array}{l}0.196^{* * *} \\
(7.27)\end{array}$ & $\begin{array}{l}0.034 \\
(0.99)\end{array}$ & -0.000 & $\begin{array}{c}0.99 \\
(0.3222)\end{array}$ & 0.68 \\
\hline
\end{tabular}

***, ${ }^{* *}$ and ${ }^{*}$ statistically significant at $10 \%, 5 \%$ and $1 \%$ level, respectively.

\subsubsection{Second approach}

To test our main hypotheses, we interact each earnings measure (OP, E-TAX, NI), CFO and accruals with an indicator variable, LSSFR, that indentifies pre- and post-LSFFR periods. In particular, LSSFR is an indicator that equals 1 for each firm-year from 2005 to 2008, which we designate as post-LSSFR period, and 0 for each firm-year from 1997 to 2004, which we designate as pre-LSFFR period. Hence, we regress returns on different measures of firm performance, augmented with interactions of different variables with LSSFR indicator. We expect that:

i) The valuation weight of each earnings variable is higher post-LSSFR than pre-LSSFR to the extent that this law is a source of improved investor confidence in financial reports.

ii) The valuation weight of total accruals is higher post-LSSFR than pre-LSSFR 


\section{Mll Macrothink}

International Journal of Accounting and Financial Reporting ISSN 2162-3082

Since a maintained view is that cash-flow from operations are less vulnerable to managerial reporting incentives, we do not make specific predictions about the extent that LSFFR will impact their valuation weights.

The models estimated are presented below:

$\mathrm{M}_{1 b}: \mathrm{RET}_{i t}=\alpha_{0}+\alpha_{1} \mathrm{OP}_{i t}+\alpha_{2} \mathrm{OP}_{i t} * \mathrm{LSFFR}+\mathrm{e}_{i t}$

$\mathrm{M}_{2 b}: \mathrm{RET}_{i t}=\alpha_{0}+\alpha_{1} \mathrm{E}_{-\mathrm{TAX}}+\alpha_{2} \mathrm{E}_{i t} \mathrm{TAX}{ }_{i t}{ }^{*} \mathrm{LSFFR}+\mathrm{e}_{i t}$

$\mathrm{M}_{3 b}: \mathrm{RET}_{i t}=\alpha_{0}+\alpha_{1} \mathrm{NI}_{i t}+\alpha_{2} \mathrm{NI}_{i t} * \mathrm{LSFFR}+\mathrm{e}_{i t}$

$\mathrm{M}_{4 b}: \mathrm{RET}_{i t}=\alpha_{0}+\alpha_{1} \mathrm{CFO}_{i t}+\alpha_{2} \mathrm{CFO}_{i t} * \mathrm{LSFFR}+\mathrm{e}_{i t}$

$\mathrm{M}_{5 b}: \mathrm{RET}_{i t}=\alpha_{0}+\alpha_{1} \mathrm{ACC}_{i t}+\alpha_{2} \mathrm{ACC}_{i t} * \mathrm{LSFFR}+\mathrm{e}_{i t}$

The coefficient on the interaction between each measure of firm performance and LSFFR, $\alpha_{2}$, evaluates the average effect of LSFFR on the weight of each variable. To the extent that LSSFR is associated with positive changes in investors' perceived credibility of earnings and accruals as indicators of value, the coefficients $\left(\alpha_{2}\right)$ will be positive. Estimations results are presented in Table 5.

Table 5. Regression results and analysis of the effect of LSSFR on the valuation weight of each earnings measure for 389 firm-year observations during the period 1997-2008

\begin{tabular}{|c|c|c|c|c|c|c|c|c|c|c|c|}
\hline \multicolumn{12}{|c|}{ Estimated Model : $R E T_{i t}=a_{0}+a_{1} E_{i t}+a_{2} E_{i t} * \mathrm{LSSFR}+e_{i t}$} \\
\hline Models & Intercept & $\begin{array}{l}E_{1} \\
\text { OP }\end{array}$ & $\begin{array}{c}E_{2} \\
\text { E-TAX }\end{array}$ & $\begin{array}{l}E_{3} \\
\mathrm{NI}\end{array}$ & $\begin{array}{c}E_{4} \\
C F O\end{array}$ & $\begin{array}{c}E_{5} \\
A C C\end{array}$ & $\begin{array}{c}E_{i} \\
* \\
L S S F R\end{array}$ & $R_{a}^{2} \%$ & $F$-Value & $V I F$ & $\begin{array}{c}F \text {-test } \\
(p \text {-value })\end{array}$ \\
\hline $\mathrm{M}_{1 \mathrm{~b}}$ & $\begin{array}{l}0.12^{* * * *} \\
(5.91)\end{array}$ & $\begin{array}{l}0.242^{* *} \\
(2.05)\end{array}$ & & & & & $\begin{array}{r}0.370^{* *} \\
(2.01)\end{array}$ & 4.46 & $10.91^{* * * *}$ & 1,45 & $\begin{array}{c}0.22 \\
(0.64)\end{array}$ \\
\hline $\mathrm{M}_{2 \mathrm{~b}}$ & $\begin{array}{c}0.13^{* * *} \\
6.36\end{array}$ & & $\begin{array}{l}0.318^{* * *} \\
(2.10)\end{array}$ & & & & $\begin{array}{l}0.201 \\
(1.13)\end{array}$ & 5.56 & $17.19^{* * * *}$ & 1.91 & $\begin{array}{c}0.14 \\
(0.71)\end{array}$ \\
\hline $\mathrm{M}_{3 \mathrm{~b}}$ & $\begin{array}{l}0.14^{* * *} \\
(6.72)\end{array}$ & & & $\begin{array}{l}0.277^{*} \\
(1.96)\end{array}$ & & & $\begin{array}{l}0.235 \\
(1.38)\end{array}$ & 4.82 & $16.88^{* * * *}$ & 1.96 & $\begin{array}{c}0.02 \\
(0.88)\end{array}$ \\
\hline $\mathrm{M}_{4 \mathrm{~b}}$ & $\begin{array}{l}0.15^{* * *} \\
(6.76)\end{array}$ & & & & $\begin{array}{c}-0.00 \\
-(0.07)\end{array}$ & & $\begin{array}{l}0.036 \\
(0.96)\end{array}$ & 0.0 & 0.60 & 1.28 & $\begin{array}{c}0.53 \\
(0.46)\end{array}$ \\
\hline $\mathrm{M}_{5 \mathrm{~b}}$ & $\begin{array}{l}0.15^{* * *} \\
(7.09)\end{array}$ & & & & & $\begin{array}{l}0.01 \\
(0.6)\end{array}$ & $\begin{array}{l}0.012 \\
(0.30)\end{array}$ & 0.0 & 0.44 & 1.30 & $\begin{array}{c}0.00 \\
(0.98)\end{array}$ \\
\hline
\end{tabular}

****** and ${ }^{*}$ statistically significant at $10 \%, 5 \%$ and $1 \%$ level, respectively.

Results show that only, the coefficient on the interaction of OP with LSSFR is positive $(0.370)$ and statistically significant $(t=2.01)$. The coefficient on the interaction of any each other measure of earnings with LSSFR is positive but statistically not significant. An $F$-test that the two coefficients are equal cannot be rejected for all variables.

Results suggest strongly that the passage of LSSFR is associated with higher valuation 


\section{Mll Macrothink}

International Journal of Accounting and Financial Reporting ISSN 2162-3082 2013, Vol. 3, No. 1

weight for operating earnings. The increases in the weights of this measure of earnings in the periods following the passage of LSSFR are perhaps largely attributable to: (i) the magnitude of long-term accruals, component of earnings, and/or (ii) the actions of less sophisticated investors. In fact, sophisticated investors have superior ability to process public and private information and may be less responsive to any changes in reporting/disclosure requirements under LSSFR. Unsophisticated investors, by contrast, lack the resources or skill to unscramble the implications of managers' reporting or disclosure incentives; for their valuation judgment, such investors rely excessively on public information and financial reports, ignoring the possible effects of managers' reporting opportunism. Under this view, disclosures under LSSFR may give this class of investors' access to corporate information that is previously available only to more sophisticated and resourceful investors. Further, unsophisticated investors react more to the internal control news than sophisticated investors. Such investors, on aggregate, are indifferent for example to the news about some deficiencies in internal control, possibly because they have anticipated and priced the implications of such deficiencies prior to the public disclosure.

\section{Conclusion}

This study provides Tunisian empirical evidence on the association of earnings measures with stock returns. More specifically, we hypothesise that $(i)$ earnings measures are weakly associated with stock returns, and (ii) the adoption in October 2005 of the Law on Strengthening the Security of Financial Relations (LSSFR) improves the transparency and the quality of accounting data and contribute to a higher relevance of earnings measures. Consistent with prior US, European and other international evidence, accounting earnings are shown to have only a weak statistical association with stock returns. It seems that adopting and implementing the TAS inspired from IFRS would not increase the value relevance of financial statements without an effective capital market infrastructure and reforms by regulators to enforce full compliance. Results show that strict compliance of accounting standards coupled with legal sanctions after 2005 may bring more value relevance to financial statements in Tunisia. Further, our results show that earnings before taxes performs better than other measures of earnings in terms of coefficient value and explanatory power.

Note, however, that there are many other potential explanations for observing a low association between realized earnings and stock returns in a given measurement interval. First, realized earnings could suffer from matching problems because the revenues and expenses from a particular productive activity are recognized in different measurement intervals. This mismatching of revenues and expenses introduces a 'noise' into the performance measures which affect the performance measure's association with stock returns. Second, realized earnings could suffer from timing problems even in absence of matching problems. This occurs when revenues and expenses, although being correctly matched (recognized in the same time problems), are reflected in stock returns in an earlier measurement interval (Dechow, 1994 and Ely and Waymire, 1999). Lev and Zarowin (1999: p 370) suggested that failure of accounting system to reflect economic changes in a timely manner often leads to a weak value relevance of earnings. Some association models use a shifted return period, which would start three months after the beginning of the fiscal year, 


\section{MInstitute Macrothink $_{\text {Int }}$}

International Journal of Accounting and Financial Reporting ISSN 2162-3082 2013, Vol. 3, No. 1

and end three months after the end of the fiscal year (Das and Lev, 1994; Hayn, 1995; Hodgson and Clarke, 2000) or expand the return measurement period with three or four months into the next year because firms are required to publish financial statements within three months of the fiscal year end. Third, errors in estimating the markets expected earnings, which might lead to a misrepresentation of the true returns/earnings association. Some researchers used earnings change as proxy for unexpected earnings, or errors in forecasts analysts.

In relation to the second hypothesis, we have tested by using two approaches whether the enactment of the Law on Strengthening the Security of Financial Relations 'LSSFR' is associated with an improvement of accounting quality in general and an increase in the value relevance of different measures of performance in particular. Our results provide evidence that the enactment of LSSFR is associated with an improvement of the value relevance of each measure of performance. However, this improvement is not statistically significant.

Our findings add to the body of research examining the factors affecting the value relevance of accounting information in in one of the emerging capital markets but should be interpreted with caution because the increase in the relationship between earnings and stock returns does not imply an increase in investor confidence in corporate financial disclosure.

In accordance with Verleun et al. (2011), future research could expand the present study by using other measures such as earnings management and/or conservatism to examine the impact of LSSFR on accounting quality and to test the robustness of our findings. Further study could focus on the impact of the disclosure of consolidated financial statements, published by listed firms after 2003 and firm characteristics such as size, growth opportunities, leverage effect on the value relevance of accounting information.

Finally, our findings are of interest to a variety of groups, including investors, management, the business press, politicians (essentially, after the Jasmin revolution on December 2010) and regulators, which have expressed interest in restoring investors' confidence in the integrity of financial statements.

\section{References}

Ball, R. and Brown, P. (1968). An empirical evaluation of accounting income numbers. Journal of Accounting Research. 6. 159-78.

Ball, R., Robin, A. and Wu, J. (2003). Incentives versus standards: properties of accounting income in four East Asian countries. Journal of Accounting and Economics. 36. 235-270.

Barth, M., Beaver, W. and Landsman, W. (2001). The relevance of the value relevance literature for financial accounting standard-setting: another view. Journal of Accounting and Economics. 31 (1-3). 77-104.

Barth, M. (2000). Valuation-based accounting research: Implications for financial reporting and opportunities for future research. Accounting and Finance. 40. 7-31.

Barth, M. E., Cram, D. P., Nelson, K.K. (2001). Accruals and the prediction of future cash 


\section{$\Lambda$ Macrothink}

International Journal of Accounting and Financial Reporting ISSN 2162-3082

flows. The Accounting Review. 76 (1). 27-58.

Basu, S. (1997). The conservatism principle and the asymmetric timeliness of earnings, Journal of Accounting and Economics. 24. 3-37.

Beaver, W. (1998). Financial Reporting: An Accounting Revolution. (2 ${ }^{\text {nd }}$ edition). Englewood Cliffs, NJ: Prentice-Hall.

Beaver, W. (2002). Perspectives on recent capital research. The Accounting Review. 77. (2), $453-474$.

Beaver, W., Lambert, R. and Morse, D. (1980). The information content of security prices. Journal of Accounting and Economics, 2, 3-28.

Beisland, L. A. (2009). A review of the value relevance literature. The Open Business Journal, 2, 7-27.

Beisland, L. A. (2010). Is the Value Relevance of Accounting Information consistently Underestimates? The Open Business Journal, 3, 1-7.

Brown, S., Lo, K. and Lys, T. (1999). Use of $\mathrm{R}^{2}$ in accounting research: measuring changes in value relevance over the last four decades. Journal of Accounting and Economics. 28. 83-115.

Charitou, A., Clubb, C. and Andreou, A. (2000). The Value Relevance of Earnings and Cash Flows: Empirical Evidence for Japan. Journal of International Financial Management and Accounting. 11. 1-22.

Charitou, A., Clubb, C. and Andreou, A. (2001). The Effects of Earnings Permanence, Growth and Firm Size on the Usefulness of Cash Flows and earnings in Explaining Security returns: Empirical Evidence for the UK. Journal of Business Finance and Accounting. 28 (5-6). 563-594.

Chen, S., Wang, Y. (2004). Evidence from China on the relevance of operating income vs. below-the-line items. The International Journal of Accounting. 39. 339-364.

Chen, C., Chen, C. and Su, X. (2001). Is accounting information value-relevant in the emerging Chinese stock market? Journal of International Accounting, Auditing and Taxation. 10. 1-22.

Cheng, A. and Yang, S. (2003). The incremental information content of earnings and cash flows from operations affected by their extremity. Journal of Business Finance and Accounting. 30 (1-2). 73-115.

Chow, G. (1960). Tests of equality between sets of coefficients in two linear regressions. Economica. 28. 591-605.

Cohen, D., A. Dey and T. Lys. (2005). Trends in earnings management and informativeness of earnings announcements in the pre- and post-Sarbanes Oxley periods. Working paper. Northwestern University.

Collins, D., Maydew, E. and Weiss, I. (1997). Changes in the value-relevance of earnings and 
book values over the past forty years. Journal of Accounting and Economics, 24: 39-67.

Das, S. and Lev, B. (1994). Nonlinearity in the return-earnings relation: tests of alternative specifications and explanations. Contemporary Accounting Research. 11. 353-379.

Dechow, P. (1994). Accounting earnings and cash flows as measures of firm performance: The role of accounting accruals. Journal of Accounting and Economics. 18. 3-42.

Doyle, J., Lundholm, R. and Soliman, M. (2003). The predictive Power of Expenses Excluded from Pro Forma Earnings. Review of Accounting Studies. 8. 145-174.

Dhaliwal, D., Subramanyam, K. and Trezevant, R. (1999). Is comprehensive income superior to net income as a measure of performance?' Journal of Accounting and Economics. 26. 43-67.

Dumontier, P. and Raffournier, B. (2002). Accounting and capital markets: a survey of the European evidence. European Accounting Review. 11 (1). 119-151.

Easton, P., Shroff, P. and Taylor, G. (2000). Permanent and transitory earnings, accounting recording lag and the earnings coefficient. Review of Accounting Studies. 5 (4). 281-300.

Easton, P. and Harris, T. (1991). Earnings as an explanatory variable for returns. Journal of Accounting Research. 29. 19-36.

Ely, K. and G. Waymire. (1999). Accounting standard-setting organizations and earnings relevance: Longitudinal evidence from NYSE common stocks, 1927-93. Journal of Accounting Research. 37. 293-317.

Francis, J. and Schipper, K. (1999). Have financial statements lost their relevance? Journal of accounting Research. 37 (2). 319-352.

Freeman, R. and Tse, S. (1992). A nonlinear model of security price responses to unexpected earnings. Journal of Accounting Research. 30. 185-209.

Gjerde, Ø. Knivsflå, K. Henry and Sættem, F. (2005). The Value Relevance of Financial Reporting on the Oslo Stock Exchange over the Period 1964-2003. http://www.nhh.no/for.

Hayn, C. (1995). The information content of losses. Journal of Accounting and Economics. 20. $125-153$.

Hodgson, A. and Stevenson-Clarke, P. (2000). Earnings, cash flows and returns: Functional relations and the Impact of Firm Size. Accounting and Finance. 40. 51-73.

IMF (2006). Report on the Observance of Standards and Codes (ROSC): Republic of Tunisia.

Jain, P.K., Rezaee, Z., (2006). The Sarbanes-Oxley Act of 2002 and capital market behavior: early evidence. Contemporary Accounting Research. 23 (3). 629-654.

Kalelkar and Nwaeze (2011). Sarbanes-Oxley Act and the quality of earnings and accruals: Market-based evidence. Journal of Accounting Public Policy. 30. 275-294.

Kothari, S. (2001). Capital markets research in accounting. Journal of Accounting and 


\section{Macrothink \\ International Journal of Accounting and Financial Reporting \\ ISSN 2162-3082 2013, Vol. 3, No. 1}

Economics. 31(1 - 3). 105-231.

Kothari, S. and Zimmerman, J. (1995). Price and return models. Journal of Accounting and Economics. 20. 155-192.

Lev, B. (1989). On the usefulness of earnings and earnings research: lessons and directions from two decades of empirical research. Journal of Accounting Research. 27. 153-201.

Lev, B., and Zarowin, P. (1999). The boundaries of financial reporting and how to extend them. Journal of Accounting Research. 37. 353-385.

Li, F. (2008). Annual report readability, current earnings, and earnings persistence. Journal of Accounting and Economics. 45. 221-247.

Lobo, G.J. and J. Zhou. (2006). Did Conservatism in Financial Reporting Increase after the Sarbanes-Oxley Act? Initial Evidence. Accounting Horizons. 20. 57-73.

Mbagwu, C. I (2007). Essays on the value relevance of earnings measures. Doctoral dissertation, University of Saskatchewan.

Newey, W. and West, K. (1987). A simple positive semi-definite, heteroscedasticity and autocorrelation consistent covariance matrix. Econometrica. 55. 703-708.

Ng, A.C., Gul, F.A., Mensah, Y.M., 2007. Managerial Entrenchment and Value-relevance of Earnings During the Pre- and Post- Sarbanes Oxley Periods. Working Paper. Hong Kong Polytechnic University and Rutgers business school.

Veith, S and Werner, J. R. (2010). Comparing Value Relevance Across Countries: Does the Return Window Specification Matter? Working paper, www.business.illinois.edu

Verleun, M, Georgakopoulos, G, Sotiropoulos, I, Konstantinos Z. Vasileiou, K, Z (2011). The Sarbanes-Oxley Act and Accounting Quality: A Comprehensive Examination. International Journal of Economics and Finance. 3 (5). 49-64. www.ccsenet.org/ijef

White, H. (1980). A heteroscedasticity consistent covariance matrix estimator and a direct test for heteroscedasticity. Econometrica. 48. 817-838.

Wilson, T, E. Jr. Financial Reporting in the Sarbanes-Oxley Era: Have Reforms Improved Earnings Quality? University of Louisiana at Lafayette. www.aabri.com/manuscripts/08090.pdf 